\title{
1 Dipicolinic acid as a novel spore-inspired excipient for antibody formulation
}

2

3 Iris L. Batalha ${ }^{1,2}$, Peng $\mathrm{Ke}^{2}$, Esther Tejeda-Montes ${ }^{2}$, Shahid Uddin ${ }^{2}$, Christopher F. van der Walle ${ }^{2 *}$ 4 and Graham Christie $e^{I^{*}}$

5

$6{ }^{1}$ Department of Chemical Engineering and Biotechnology, University of Cambridge, Philippa Fawcett 7 Drive, Cambridge, CB3 0AS, UK

$8 \quad{ }^{2}$ Formulation Sciences, MedImmune, Ltd., Aaron Klug Building, Granta Park, Cambridge CB21 $96 \mathrm{GH}, \mathrm{UK}$

*Corresponding authors: Graham Christie (gc301@,cam.ac.uk) and Christopher van der Walle (wallec@medimmune.com).

Keywords: antibody formulation, novel excipients, dipicolinic acid, bacterial spores

\section{Abstract}

Ionic excipients are commonly used in aqueous therapeutic monoclonal antibody (mAb) formulations. Novel excipients are of industrial interest, with a recent focus on Arg salt forms and their application as viscosity reducing and stabilizing additives. Here, we report that the calcium salt of dipicolinic acid (DPA, pyridine-2,6-dicarboxylic acid), uniquely present in nature in the core of certain bacterial spores, reduces the viscosity of a mAb formulated at $150 \mathrm{mg} / \mathrm{mL}$, below that achieved by Arg hydrochloride at the same concentration $(10 \mathrm{mM})$. DPA also reduced the reversible phase separation of the same formulation, which characteristically occurs for this mAb upon cooling to $4^{\circ} \mathrm{C}$. 
destabilization of the $\mathrm{mAb}$ in the presence of $10 \mathrm{mM}$ DPA, or by the related quinolinic acid (QA, pyridine-2,3-dicarboxylic acid). However, fluorescence spectrophotometry did reveal localized (aromatic) conformational changes to the mAb attributed to DPA, dependent on the salt form. While precise mechanisms of action remain to be identified, our preliminary data suggest that these DPA salts are worthy of further investigation as novel ionic excipient for biologics formulation.

\section{Introduction}

Bacterial cells of the orders Bacillales and Clostridiales initiate the process of sporulation upon sensing conditions of nutrient limitation. Sporulation is a tightly regulated cellular differentiation process that results in the formation of an endospore (hereafter spore), a metabolically dormant celltype that is adapted to resist physico-chemical and biological challenges for extended periods of time (Higgins and Dworkin, 2012; Tan and Ramamurthi, 2014). Whereas the primary protective feature of spores comprises an outermost proteinaceous coat that functions as a molecular barrier to chemical and enzymatic attack (McKenney et al., 2013), dormancy is achieved principally by two means. First, the cellular protoplast is surrounded by a thick layer of modified peptidoglycan, referred to as the cortex, which probably mechanically enforces the reduced water content of the spore core (ParedesSabja et al., 2011). Second, the spore core environment is highly mineralised with calcium and other divalent metal ions, which are chelated with pyridine-2,6-dicarboxylic acid (dipicolinic acid or DPA). The latter is uniquely associated with bacterial spores in nature, comprising approximately $10-15 \%$ of the dry weight of spores (Paredes-Sabja et al., 2011). While the precise function of DPA in spores has not definitively been elucidated, it clearly has a role in the maintenance of spore dormancy i.e. mutant strains of Bacillus that lack enzymes involved in DPA synthesis are unstable and lyse before maturity (Paredes-Sabja et al., 2011; Setlow, 2014). Similarly, the induced release of DPA from the spore core - whether achieved via nutrient induced germination, or by exposure of spores to certain cationic surfactants or extremely high pressures - results in the loss of spore dormancy and resistance properties (Setlow, 2014).

One potential role for DPA at the molecular level is to promote the stability of essential spore-core located proteins during dormancy and spore germination, perhaps by minimising thermal-induced 
motion and the likelihood of denaturation and aggregation. Given the apparent protective role of DPA in spores, we conjectured whether it would be able to fulfil a similar function as an excipient to pharmaceutical proteins of interest. The most commonly used pharmaceutical excipients include amino acids, polyols, salts, sugars, and surfactants (Manikwar et al., 2013). However, considerable effort has been made in recent years to identify and develop new excipients that mitigate the physical and chemical instability of biological drugs (Du and Klibanov, 2011; Lee et al., 2014). The use of novel Arg salts, for example, including equimolar formulations with glutamic acid, have been reported to exert synergistic effects in terms of reducing intermolecular attractions and aggregation, compared to Arg.HCl alone (Kheddo et al., 2016; Kheddo et al., 2014).

Here we report on the use of DPA, and its quinolinic acid (QA) analogue, as novel excipients that may have potential in $\mathrm{mAb}$ formulation. This class of biopharmaceutical is of particular interest since subcutaneous injections of $\mathrm{mAbs}$ comprise low volume $(<1.5 \mathrm{ml})$ high protein concentration $(>100$ $\mathrm{mg} / \mathrm{ml}$ ) formulations. Such conditions promote aggregation, reversible self-association and particulate formation, with the resultant solubility and viscosity issues presenting considerable challenges to large-scale manufacture, product stability and delivery (Shire et al., 2004).

\section{Materials and Methods}

\subsection{Chemicals and reagents}

All reagents were purchased at $>98 \%$ purity. 2,3-Pyridinedicarboxylic acid (quinolinic acid or QA), 2,6-pyridinedicarboxylic acid (DPA), Bradford Reagent, calcium hydroxide, lysozyme and Scienceware ${ }^{\circledR}$ Aquet ${ }^{\circledR}$ liquid detergent were purchased from Sigma-Aldrich (Dorset, UK). Arg, Arg hydrochloride, histidine, histidine hydrochloride, and sodium chloride were acquired from J. T. Baker (Avantor Performance Materials B.V., Deventer, Netherlands). Calcium chloride dihydrate, SYPRO Orange protein gel stain 5000× in DMSO, and Tergazyme were obtained from Macron Chemicals (UK), Invitrogen (Paisley, UK) and Alconox (UK), respectively. MAb A is an IgG1 isotype with MW of $148.2 \mathrm{kDa}$, extinction coefficient or $1.443 \mathrm{~cm}^{2} / \mathrm{mg}$ and $\mathrm{pI} 9.30$. MAb B is an IgG1 isotype with MW of $148.4 \mathrm{kDa}$, extinction coefficient of $1.58 \mathrm{~cm}^{2} / \mathrm{mg}$ and $\mathrm{pI} 7.5-7.8$. MAb C is an IgG1 isotype with MW of $149.0 \mathrm{kDa}$, extinction coefficient of $1.55 \mathrm{~cm}^{2} / \mathrm{mg}$ and $\mathrm{pI} 9.04$. MAbs A, B and C were 
kindly provided by MedImmune Ltd., Cambridge, supplied at $50 \mathrm{mg} / \mathrm{mL}$ solution and stored at $-80^{\circ} \mathrm{C}$ until use.

\subsection{Sample preparation}

MAb A was defrosted on the bench and gently swirled to mix; $45 \mathrm{~mL}$ at $50 \mathrm{mg} / \mathrm{mL}$ was then dialysed against $5 \mathrm{~L}$ of $25 \mathrm{mM}$ His, $120 \mathrm{mM} \mathrm{NaCl}$, pH 6 buffer for two days using dialysis cassettes (Thermo Scientific, Slide-A-Lyzer, $30 \mathrm{kDa}$ MWCO). Dialysis buffer was changed after $3 \mathrm{~h}$ and after $12 \mathrm{~h}$ dialysis. After dialysis, the protein concentration was determined by absorbance at $280 \mathrm{~nm}$ using a NanoDrop instrument (Thermo Fisher Scientific Inc., Wilmington, USA). mAb A was then concentrated to $150 \mathrm{mg} / \mathrm{mL}$ using a Microsep Advance Centrifugal Device with a 30kD MWCO (Pall Corporation, NY, USA) in the absence or presence of different QA and DPA complexes. Before concentration, mAb A was diluted 1:2 using (1) $20 \mathrm{mM} \mathrm{Ca}(\mathrm{OH})_{2} 20 \mathrm{mM} \mathrm{QA}$; (2) $20 \mathrm{mM} \mathrm{Ca}(\mathrm{OH})_{2} 20$ mM DPA; (3) 20 mM CaCl $2.2 \mathrm{H}_{2} \mathrm{O}$; (4) 40 mM Arg 20 mM QA; (5) 40 mM Arg 20 mM DPA; (6) 40 mM Arg.HCl. Since both QA and DPA absorb ultra-violet light, the protein concentration was determined by Bradford assay. Briefly, protein samples were diluted $2000 \times$ in the same buffer they were prepared in and $50 \mu \mathrm{L}$ of each sample added to a $96-$-well microplate. A calibration curve $(0-0.25$ $\mathrm{mg} / \mathrm{mL}$ ) was prepared using mAb A in $25 \mathrm{mM}$ His, $120 \mathrm{mM} \mathrm{NaCl}$, pH6. $200 \mu \mathrm{L}$ of Bradford reagent was added to each well before incubating with mild agitation at room temperature in the dark for 20 min. Sample absorbance was read subsequently at $595 \mathrm{~nm}$.

\subsection{Determination of mAb A thermal stability by differential scanning calorimetry (DSC)}

$1 \mathrm{mg} / \mathrm{mL} \mathrm{mAb}$ A samples were prepared in buffers containing various QA and DPA complexes at a range of concentrations. The following stock solutions used to prepare the samples: $50 \mathrm{mg} / \mathrm{mL} \mathrm{mAb}$ A in $25 \mathrm{mM}$ His, $120 \mathrm{mM} \mathrm{NaCl}$, pH 6; $20 \mathrm{mM}$ DPA (or QA) in $90 \mathrm{mM}$ His, $120 \mathrm{mM} \mathrm{NaCl}, \mathrm{pH}$ 6; 20 $\mathrm{mM} \mathrm{Ca}(\mathrm{OH})_{2}, 20 \mathrm{mM}$ DPA (or QA), $25 \mathrm{mM}$ His, $120 \mathrm{mM} \mathrm{NaCl}$, pH6; $40 \mathrm{mM} \mathrm{Arg,} 20 \mathrm{mM}$ DPA (or QA), $25 \mathrm{mM}$ His, $120 \mathrm{mM} \mathrm{NaCl}$, pH6. Buffer strength had to be increased to $90 \mathrm{mM}$ His instead of $25 \mathrm{mM}$ His in order to maintain a stable $\mathrm{pH}$ in the presence of $20 \mathrm{mM}$ DPA or QA free acids. Samples were prepared using these stock solutions and then diluted in $25 \mathrm{mM} \mathrm{His,} 120 \mathrm{mM} \mathrm{NaCl}$, pH 6 to 
achieve the desired QA and DPA concentrations. Buffers and MilliQ water were degassed by sonication, whereas protein samples were degassed using a degassing station (TA Instruments). Lysozyme was used as a reference protein. $900 \mu \mathrm{L}$ of each sample and buffer were pipetted into a 96deepwell plate and samples were heated from $25-90^{\circ} \mathrm{C}$ using a rate of $2^{\circ} \mathrm{C} / \mathrm{min}$ and an equilibration time of $600 \mathrm{~s}$ using a NanoDSC differential scanning calorimeter (TA Instruments). Data analysis was performed in NanoAnalyze 3.6.0 software (TA Instruments). DSC curves were fitted using a two-state model of three independent domains to determine the melting temperature $\left(\mathrm{T}_{\mathrm{m}}\left({ }^{\circ} \mathrm{C}\right)\right)$ and enthalpy difference $(\Delta \mathrm{H}(\mathrm{KJ} / \mathrm{mol})$ during thermal denaturation of each domain. The entropy difference $(\Delta \mathrm{S}$ $(\mathrm{KJ} / \mathrm{mol} . \mathrm{K}))$ was determined using the following equation: $\Delta \mathrm{S}=\Delta \mathrm{H} /\left(\mathrm{T}_{\mathrm{m}}+273.15\right)$

\subsection{Determination of tertiary structure modifications by intrinsic fluorescence spectroscopy} $1 \mathrm{mg} / \mathrm{mL} \mathrm{mAb}$ A in DPA (or QA), $\mathrm{Ca}^{2+}$-DPA (or QA), Arg-DPA (or QA) (2:1) with DPA or QA concentrations ranging from $0-10 \mathrm{mM}$ were prepared before adding $300 \mu \mathrm{L}$ of each sample to a black 96-well microplate (in sextuplicates). Fluorescence emission was monitored between 300-400 nm using a Hitachi F-7000 fluorescence spectrophotometer. Stock solutions and samples were prepared as in $\mathbf{2 . 3}$.

\subsection{Assessing the conformational stability of mAb A solutions by differential scanning}

\section{fluorimetry (DSF)}

An intermediate protein stock solution was prepared by adding $2 \mu \mathrm{L}$ SYPRO Orange (5000×) to 49 $\mu \mathrm{L}$ of $50 \mathrm{mg} / \mathrm{mL} \mathrm{mAb} \mathrm{A}$ and $144 \mu \mathrm{L} 25 \mathrm{mM}$ His, $120 \mathrm{mM} \mathrm{NaCl}$, pH 6 buffer to a final protein concentration of $12.5 \mathrm{mg} / \mathrm{mL}$. The sample was vortexed and protected from light. The intermediate protein stock solution $(2 \mu \mathrm{L})$ was pipetted to individual wells of a 96-well microplate along with 23 $\mu \mathrm{L}$ of each buffer of interest (in triplicates). The buffers consisted of $25 \mathrm{mM}$ His, $120 \mathrm{mM} \mathrm{NaCl}, \mathrm{pH} 6$ with: $1 \mathrm{mM}, 5 \mathrm{mM}$ and $10 \mathrm{mM}$ of DPA or QA; $10 \mathrm{mM} \mathrm{Ca}(\mathrm{OH})_{2}, 10 \mathrm{mM}$ DPA; $10 \mathrm{mM} \mathrm{Ca}(\mathrm{OH})_{2}, 10$ mM QA; 10 mM CaCl $2.2 \mathrm{H}_{2} \mathrm{O} ; 20$ mM Arg.HCl; 20 mM Arg, 10 mM DPA; 20 mM Arg, 20 mM QA. Thermal unfolding of mAb A then monitored using a Biorad CFX96 Real-Time PCR system using a temperature range of $20^{\circ} \mathrm{C}$ to $95^{\circ} \mathrm{C}$ with an increment of $0.2^{\circ} \mathrm{C} \cdot \mathrm{min}^{-1}$ and a hold time of $10 \mathrm{~s}$. As mAb 
137 A unfolds, SYPRO Orange binds to its exposed hydrophobic surfaces, resulting in an increase of

138 fluorescence. Two unfolding events most likely associated with unfolding of $\mathrm{CH} 2$ and $\mathrm{CH} 3$ domains

139 of mAb A are observed at temperature of hydrophobicity 1 (Th1) and temperature of hydrophobicity 2

140 (Th2), respectively.

\subsection{Cloud point assays}

$\mathrm{mAb} A$ at an initial concentration of $100 \mathrm{mg} / \mathrm{mL}$ was diluted 1:2 in the following buffers: $20 \mathrm{mM}$

$\mathrm{Ca}(\mathrm{OH})_{2}, 20 \mathrm{mM}$ QA; $20 \mathrm{mM} \mathrm{Ca}(\mathrm{OH})_{2}, 20 \mathrm{mM} \mathrm{DPA} ; 20 \mathrm{mM} \mathrm{CaCl} 2.2 \mathrm{H}_{2} \mathrm{O} ; 40 \mathrm{mM}$ Arg, $20 \mathrm{mM}$ QA;

$40 \mathrm{mM}$ Arg, $20 \mathrm{mM}$ DPA; and $40 \mathrm{mM} \mathrm{Arg.HCl.} 800 \mu \mathrm{L}$ of each sample was added to a quartz cuvette and the absorbance measured at $450 \mathrm{~nm}$ using a Cary $100 \mathrm{UV}-\mathrm{Vis}$ spectrophotometer equipped with a multicell Peltier and circulating water bath. As samples were cooled from $25^{\circ} \mathrm{C}$ to $4{ }^{\circ} \mathrm{C}$ the absorbance was read incrementally at $0.5^{\circ} \mathrm{C}$ intervals.

\subsection{Viscosity measurements}

A $1 \mathrm{~mL}$ syringe was filled with mAb A at different concentrations $(45,75,100$ and $150 \mathrm{mg} / \mathrm{mL})$ in 25 mM His, $120 \mathrm{mM} \mathrm{NaCl}$, pH 6 containing different excipients: $10 \mathrm{mM} \mathrm{CaCl}_{2} .2 \mathrm{H}_{2} \mathrm{O} ; 10 \mathrm{mM} \mathrm{Ca}(\mathrm{OH})_{2}$, $10 \mathrm{mM}$ QA, $10 \mathrm{mM} \mathrm{Ca}(\mathrm{OH})_{2}, 10 \mathrm{mM}$ DPA; $20 \mathrm{mM}$ Arg.HCl; $20 \mathrm{mM} \mathrm{Arg,} 10 \mathrm{mM}$ QA; and $20 \mathrm{mM}$ Arg, 10 mM DPA. Sample viscosity was measured using an $\mathrm{m}-\mathrm{VROC}^{\mathrm{TM}}$ viscometer (Rheosense, Inc., San Ramon, CA, USA). The chip was flushed with each sample for $10 \mathrm{~s}$ at a shear rate of $6000 \mathrm{~s}^{-1}$ and $23^{\circ} \mathrm{C}$, followed by a second injection for $30 \mathrm{~s}$ at a shear rate of $6000 \mathrm{~s}^{-1}$ at $23^{\circ} \mathrm{C}$. The viscosity value measured during the second injection was considered to be more accurate. Between each sample measurement, the chip was flushed at a flow rate of $750 \mu \mathrm{L} \mathrm{min}^{-1}$ for $60 \mathrm{~s}$ in a sequential manner with the following solutions: $1 \%$ tergazyme, $1 \%$ aquet, filtered MilliQ water and sample buffer.

2.8 Analysis of protein aggregation and fragmentation using High Performance Size Exclusion

All samples were stored in $3 \mathrm{~mL}$ clear vials at 5 and $40{ }^{\circ} \mathrm{C}$. HPSEC analysis was performed on an 
different time points: 0,4 weeks (at $5{ }^{\circ} \mathrm{C}$ and $40^{\circ} \mathrm{C}$ ) and 12 weeks (at $5{ }^{\circ} \mathrm{C}$ ). The HPLC system was equipped with a multiple wavelength UV detector set at $280 \mathrm{~nm}$ wavelength. The samples were diluted to a concentration of $10 \mathrm{mg} / \mathrm{mL}$ using phosphate buffered saline (PBS) before loading into the column at an injection volume of $25 \mu \mathrm{L}$. The mobile phase used was $0.1 \mathrm{M}$ sodium phosphate dibasic anhydrous $0.1 \mathrm{M}$ sodium sulphate $\mathrm{pH} 6.8$.

\section{Results}

\subsection{Thermal stability of QA and DPA-containing formulations}

A DSC thermogram of mAb A is illustrated in Figure 1, revealing three visible unfolding events represented by three different peaks. The first peak refers to the unfolding of the $\mathrm{CH} 2$ domain at 67.9 ${ }^{\circ} \mathrm{C}$, followed by a second peak associated with the unfolding of the $\mathrm{CH} 3$ domain at $77.0^{\circ} \mathrm{C}$. Unfolding of the Fab fragment is represented by the peak at $84.0^{\circ} \mathrm{C}$ (Fukuda et al., 2014; Kameoka et al., 2007). Values of $\mathrm{T}_{\mathrm{m}}, \Delta \mathrm{H}$, and $\Delta \mathrm{S}$ were determined for $\mathrm{mAb} \mathrm{A}$ in the presence of QA and DPA, either alone or complexed with $\mathrm{Ca}^{2+}$ or Arg. Table 1 lists changes in these values $\left(\Delta \mathrm{T}_{\mathrm{m}}, \Delta \Delta \mathrm{H}\right.$, and $\left.\Delta \Delta \mathrm{S}\right)$ compared to the values obtained for $\mathrm{mAb} \mathrm{A}$ in $25 \mathrm{mM}$ His $120 \mathrm{mM} \mathrm{NaCl} \mathrm{pH} 6$ without the addition of any organic acid. The differences on melting temperatures were negligible and never above $0.5^{\circ} \mathrm{C} . \Delta \Delta \mathrm{S}$ values followed the same trend in the presence of any of the organic acids even at low concentrations, with no significant variation on entropy associated with $\mathrm{CH} 2$ domain $(\Delta \Delta \mathrm{S} \approx 0)$. CH3 and Fab domains presented positive $\Delta \Delta \mathrm{S}$ values in the same order of magnitude and always larger for the Fab domain, which are associated with entropic gain of the $\mathrm{mAb}$ in the presence of the organic acid.

Table 1 - Differences in $\mathrm{T}_{\mathrm{m}}\left(\Delta \mathrm{T}_{\mathrm{m}}\left({ }^{\circ} \mathrm{C}\right)\right), \Delta \mathrm{H}(\Delta \Delta \mathrm{H}(\mathrm{KJ} / \mathrm{mol}))$, and $\Delta \mathrm{S}(\Delta \Delta \mathrm{S}(\mathrm{KJ} / \mathrm{mol} . \mathrm{K})$ for $\mathrm{mAb} \mathrm{A}$ in the presence of DPA or QA in different concentrations and complexed with either $\mathrm{Ca}^{2+}$ or $\operatorname{Arg}(2: 1)$.

\begin{tabular}{lllll} 
Organic acid & Domain & $\Delta \mathbf{T}_{\mathbf{m}}\left({ }^{\mathbf{}} \mathbf{C}\right)$ & $\Delta \Delta \mathbf{H}(\mathbf{K J} / \mathbf{m o l})$ & $\Delta \Delta \mathbf{S}(\mathbf{K J} / \mathbf{m o l} . \mathbf{K})$ \\
\hline \multirow{2}{*}{ No Organic Acid } & $\mathrm{CH} 2$ & - & - & - \\
& $\mathrm{CH} 3$ & - & - & - \\
& $\mathrm{Fab}$ & - & - & - \\
\hline 1mM DPA & $\mathrm{CH} 2$ & -0.12 & 8.5 & 0.03 \\
& $\mathrm{CH} 3$ & -0.03 & -16.7 & 1.15
\end{tabular}




\begin{tabular}{|c|c|c|c|c|}
\hline & $\mathrm{Fab}$ & 0.12 & -74.2 & 1.96 \\
\hline \multirow{3}{*}{ 5mM DPA } & $\mathrm{CH} 2$ & -0.3 & -52.5 & -0.15 \\
\hline & $\mathrm{CH} 3$ & -0.3 & -2.4 & 1.19 \\
\hline & $\mathrm{Fab}$ & -0.21 & 15 & 2.21 \\
\hline \multirow{3}{*}{ 10mM DPA } & $\mathrm{CH} 2$ & -0.53 & -33.8 & -0.10 \\
\hline & $\mathrm{CH} 3$ & -0.09 & -3.9 & 1.19 \\
\hline & $\mathrm{Fab}$ & 0.08 & -149.3 & 1.75 \\
\hline \multirow{3}{*}{$10 \mathrm{mM} \mathrm{Ca}{ }^{2+}-\mathrm{DPA}$} & $\mathrm{CH} 2$ & 0.15 & -43.3 & -0.13 \\
\hline & $\mathrm{CH} 3$ & 0.07 & -17.3 & 1.15 \\
\hline & $\mathrm{Fab}$ & 0.14 & 56 & 2.33 \\
\hline \multirow{3}{*}{ 20mM Arg 10mM DPA } & $\mathrm{CH} 2$ & -0.1 & -16.3 & -0.05 \\
\hline & $\mathrm{CH} 3$ & 0.12 & 4.1 & 1.21 \\
\hline & $\mathrm{Fab}$ & 0.04 & 6 & 2.19 \\
\hline \multirow{3}{*}{ 1mM QA } & $\mathrm{CH} 2$ & 0.32 & -33.2 & -0.10 \\
\hline & $\mathrm{CH} 3$ & 0.16 & -14.4 & 1.15 \\
\hline & $\mathrm{Fab}$ & 0.37 & -104.3 & 1.88 \\
\hline \multirow{3}{*}{ 5mM QA } & $\mathrm{CH} 2$ & 0.07 & 13.1 & 0.04 \\
\hline & $\mathrm{CH} 3$ & 0.12 & -0.8 & 1.19 \\
\hline & $\mathrm{Fab}$ & 0.15 & 97 & 2.44 \\
\hline \multirow{3}{*}{ 10mM QA } & $\mathrm{CH} 2$ & 0.02 & -104.2 & -0.31 \\
\hline & $\mathrm{CH} 3$ & 0.19 & -6.6 & 1.18 \\
\hline & $\mathrm{Fab}$ & 0.04 & 44 & 2.29 \\
\hline \multirow{3}{*}{$10 \mathrm{mM} \mathrm{Ca}^{2+}-\mathrm{QA}$} & $\mathrm{CH} 2$ & 0.31 & -19.6 & -0.06 \\
\hline & $\mathrm{CH} 3$ & 0.28 & -4.4 & 1.18 \\
\hline & $\mathrm{Fab}$ & 0.35 & -11 & 2.14 \\
\hline \multirow{3}{*}{ 20mM Arg 10mM QA } & $\mathrm{CH} 2$ & 0.43 & -12.9 & -0.04 \\
\hline & $\mathrm{CH} 3$ & 0.41 & -4.9 & 1.18 \\
\hline & $\mathrm{Fab}$ & 0.32 & 126 & 2.52 \\
\hline
\end{tabular}

\subsection{Assessment of local higher structure by intrinsic fluorescence spectrophotometry and DSF}

Fluorescence spectrophotometry methods may be used to assess conformational changes of polypeptides by exploiting the intrinsic fluorescence of aromatic amino acids (e.g. Trp). When a polypeptide unfolds or changes conformation, there is a change in the polarity of the microenvironment surrounding the aromatic amino acids, leading to a change in average emission fluorescence wavelength (e.g. $330 \mathrm{~nm}$ in a polypeptide where a Trp is fully buried to $350 \mathrm{~nm}$ where a Trp is fully exposed to the aqueous environment). In this study, the maximum emission wavelength was kept at $330 \mathrm{~nm}$ for the $\mathrm{mAb}$ in the presence of either DPA or QA acids or salts. However, a decrease in fluorescence intensity at $330 \mathrm{~nm}$ was observed with increasing concentrations of the organic acids (DPA and QA) (Figure 2), indicating local changes in the polarity of the 
microenvironment surrounding the aromatic amino acids. This decrease in fluorescence may be due to quenching, indicating a conformational change in the polypeptide upon increased exposure of aromatic amino acids to solvent. At room temperature in the presence of DPA, local changes to the aromatic environment were attenuated by the $\mathrm{Ca}^{2+}$ (Figure 2, filled black squares) but not the Arg (Figure 2, open black triangles) salt forms. The interaction between organic acids and either $\mathrm{Ca}^{2+}$ or Arg is different: $\mathrm{Ca}^{2+}$ acts as a chelating agent, forming a bidentate bond between the calcium cation and two carboxylic groups of the organic acid, whereas Arg forms an ionic interaction between its charged amino group and the negatively charged carboxylic groups of the organic acids. These differences could conceivably affect the quenching process. In contrast, fluorescence intensity of mAb A in the presence of Arg-QA (2:1) (Figure 2, grey open circles) is always slightly higher than in the presence of $\mathrm{Ca}-\mathrm{QA}$ or $\mathrm{QA}$, indicating that the $\mathrm{mAb} \mathrm{A}$ was less exposed to the aqueous environment. Notably, these results are in accordance with DSC data presented in Table 1. The Fab fragment of $\mathrm{mAb} \mathrm{A}$ is thermodynamically stabilized by enthalpic gain $(\Delta \Delta \mathrm{H}=126 \mathrm{~kJ} / \mathrm{mol})$ plus entropic gain $(\Delta \Delta \mathrm{S}=2.52 \mathrm{~kJ} / \mathrm{mol} . \mathrm{K})$ in the presence of Arg-QA (2:1).

Conformational stability of polypeptides can also be assessed using Real-Time PCR-type instrumentation with an appropriate fluorescent dye (e.g. SYPRO Orange). In such systems folded polypeptides do not bind to the fluorescent dye, producing low extrinsic fluorescence signals. As the polypeptide unfolds or changes conformation, the fluorescent dye binds to the exposed hydrophobic regions producing increased extrinsic fluorescence intensity. In the current work, no significant difference in the temperature of hydrophobicity of mAb A was observed in the presence of variable concentrations of either QA or DPA, or when in the salt form with either $\mathrm{Ca}^{2+}$ or $\operatorname{Arg}$ (Figure 3). Again, these results are consistent with the DSC results, indicating that mAb A remains folded in the presence of the organic acids.

\subsection{Reduction of opalescence by QA and DPA-containing formulations}

Opalescence is a phase transition which is observed when density fluctuations of fluids near the critical transition point result in scattering of light (Kamerzell et al., 2011; Salinas et al., 2010). This results in the solution developing a cloudy-white and translucent appearance. The degree of 
opalescence can be influenced by temperature, ionic strength, protein concentration and/or addition of excipients (Kamerzell et al., 2011). In this work, opalescence was determined by measuring the absorbance of $50 \mathrm{mg} / \mathrm{mL} \mathrm{mAb}$ A solutions at $450 \mathrm{~nm}$ in the presence of different excipients. This wavelength was selected due to the fact that the pyridine ring absorbs UV light; therefore, absorbance was measured in the visible light region. Even though we did not determine the critical opalescence concentration for the $\mathrm{mAb}$ used in this study, the protein concentration was kept at $50 \mathrm{mg} / \mathrm{mL}$, since $\mathrm{mAb}$ solutions at higher concentrations $(150 \mathrm{mg} / \mathrm{mL})$ were completely clear. The absorbance of $\mathrm{mAb}$ A solutions was measured at different temperatures - ranging from $4^{\circ} \mathrm{C}$ to $25^{\circ} \mathrm{C}$ - in the presence of different excipients (Figure 4). At $4{ }^{\circ} \mathrm{C}, \mathrm{mAb} \mathrm{A}$ in buffer presented the highest degree of opalescence, as adjudged by association with the highest absorbance value. Opalescence decreased in the following order: $\mathrm{Ca}^{2+}-\mathrm{DPA}>\mathrm{CaCl}_{2} \cdot 2 \mathrm{H}_{2} \mathrm{O}>\mathrm{Arg} \cdot \mathrm{HCl}=\mathrm{Ca}^{2+}-\mathrm{QA}>\operatorname{Arg}-\mathrm{DPA}(2: 1)>\operatorname{Arg}-\mathrm{QA}(2: 1)$. Essentially, all tested salts of DPA and QA attenuated temperature-induced opalescence of mAb A, with Arg salts of DPA and QA outperforming Arg.HCl. The same trends were observed with increasing temperatures, although the differences between excipients were less obvious at $25^{\circ} \mathrm{C}$.

\subsection{QA and DPA as viscosity modulators}

The ability of DPA and QA to reduce the viscosity of mAb A liquid formulations was also investigated. $\mathrm{mAb}$ A at a concentration of $150 \mathrm{mg} / \mathrm{mL}$ in $25 \mathrm{mM}$ His $120 \mathrm{mM} \mathrm{NaCl} \mathrm{pH} 6 \mathrm{had}$ a viscosity of $53.77 \mathrm{cP}$. However, $\mathrm{mAb}$ A at concentrations up to $150 \mathrm{mg} / \mathrm{mL}$ showed a marked decrease in viscosity when formulated with low concentrations of any of the excipients tested (Figure 5), with the viscosity decreasing in the following order: $\mathrm{Arg} . \mathrm{HCl}>\mathrm{CaCl}_{2} \cdot 2 \mathrm{H}_{2} \mathrm{O}>\mathrm{Ca}^{2+}-\mathrm{DPA}>\mathrm{Ca}^{2+}-$ $\mathrm{QA}=\operatorname{Arg}-\mathrm{DPA}(2: 1)=\operatorname{Arg}-\mathrm{QA}(2: 1)$. The viscosity of mAb A in the presence of $\mathrm{Ca}^{2+}-\mathrm{QA}, \mathrm{Arg}-\mathrm{DPA}$ (2:1) and Arg-QA (2:1) was reduced approximately 4.5 times when compared to mAb A in His saline buffer, and 2.5 times when compared to $\mathrm{mAb}$ A formulated with the same concentration of Arg. $\mathrm{HCl}$ (Figure 5).

\subsection{Time- and thermal-stability of DPA-containing formulations}


To exploit the broader applicability of DPA as a pharmaceutical excipient, we have further

257 investigated the stability of two additional $\mathrm{mAbs}(\mathrm{mAb} \mathrm{B}$ and $\mathrm{mAb} \mathrm{C})$ formulated with DPA. DPA concentrations were increased up to $100 \mathrm{mM}$ (200 mM Arg - $100 \mathrm{mM}$ DPA) to understand the effects of higher excipient concentration on protein stability. Arg salts were selected over $\mathrm{Ca}^{2+}$ salts due to the limited aqueous solubility of Ca-DPA. Arg. $\mathrm{HCl}$ was used as a positive control (at $200 \mathrm{mM}$ ). After 4 weeks at $40^{\circ} \mathrm{C}$, aggregation was significantly reduced for both mAbs B and $\mathrm{C}$ for formulations containing either Arg. $\mathrm{HCl}$ or Arg-DPA, while there was a slight increase in fragmentation. At $5^{\circ} \mathrm{C}$ there was no increase in aggregation or fragmentation even after 12 weeks (Table 2).

Table 2 - Percentage of monomer (\%Mon), aggregates (\%Agg) and fragmentation (\%Frag) of mAb B and $\mathrm{mAb} \mathrm{C}$ at $5^{\circ} \mathrm{C}$ and $40^{\circ} \mathrm{C}$ measured by HPSEC. Controls were molecules in their base buffer: $\mathrm{mAb} \mathrm{B}$ in $50 \mathrm{mM}$ sodium acetate $\mathrm{pH} 5.5$ and $\mathrm{mAb} \mathrm{C}$ in $20 \mathrm{mM}$ sodium succinate $\mathrm{pH}$ 6.0, respectively.

\begin{tabular}{|c|c|c|c|c|c|c|c|c|c|c|}
\hline Sample & Formulation & \%Mon & $\%$ Agg & $\%$ Frag & \%Mon & $\% \mathrm{Agg}$ & $\%$ Frag & $\%$ Mon & $\%$ Agg & $\%$ Frag \\
\hline \multirow[t]{3}{*}{$\mathrm{mAb} B$} & Control & 98.46 & 1.37 & 0.17 & 26.37 & 71.02 & 2.61 & 97.91 & 1.9 & 0.19 \\
\hline & Arg.HCl & 98.71 & 1.13 & 0.16 & 91.58 & 4.55 & 3.87 & 98.75 & 1.05 & 0.2 \\
\hline & Arg-DPA & 98.76 & 1.1 & 0.15 & 84.06 & 9.67 & 6.27 & 98.72 & 1.09 & 0.19 \\
\hline \multirow[t]{3}{*}{$\mathrm{mAb} C$} & Control & 96.98 & 3.02 & 0 & 90.23 & 8.85 & 0.92 & 96.55 & 3.45 & 0 \\
\hline & Arg. $\mathrm{HCl}$ & 97.1 & 2.9 & 0 & 91.22 & 3.85 & 4.82 & 96.38 & 3.62 & 0 \\
\hline & Arg-DPA & 97.1 & 2.9 & 0 & 90.14 & 3.54 & 6.32 & 96.82 & 3.10 & 0.08 \\
\hline
\end{tabular}


272 The stability of protein-based liquid formulations is of significant interest to the pharmaceutical

273 industry, since the physical instability of biopharmaceuticals can undermine their safety and efficacy.

274 This is particularly relevant at the high protein concentrations required typically for therapeutic administration, where non-specific aggregation is more likely to occur. As such, excipient molecules, such as Arg, are added to biopharmaceutical drugs in order to supress aggregation, minimise phase separation, reduce viscosity and increase the shelf life of the product. The underlying mechanisms associated with Arg-mediated suppression of aggregation have not been definitively established but may involve protein-liquid surface tension effects, preferential surface interactions, and/or binding of the Arg guanidinium group to indole groups associated with Trp residues (Tsumoto et al., 2004). The role of the anion in Arg salt excipients is also important in terms of conferring protein stability (Schneider et al., 2011; Zhang et al., 2016). However, the addition of Arg. $\mathrm{HCl}$ is not a universal solution for all formulations. The generation of NOx by Arg and related compounds may also confer physico-chemical destabilising effects on biopharmaceutical formulations (Kim et al., 2016). Thus, there is a clear rationale for the introduction of alternative excipients that are useful for attenuating high concentration $\mathrm{mAb}$ formulations. Inspired by the employment of $\mathrm{Ca}^{2+}$-DPA by bacterial spores to promote protein stability during dormancy, this work sought to examine whether DPA and the QA analogue could function as novel excipients in the formulation of a model mAb. Results from the work demonstrated that the viscosity of relatively high concentration mAb A solutions markedly decreased when formulated with low concentrations of Arg-QA (2:1), Arg-DPA (2:1) and $\mathrm{Ca}^{2+}$-QA. Moreover, these excipients performed considerably better than both $\mathrm{Arg} \cdot \mathrm{HCl}$ and $\mathrm{CaCl}_{2} \cdot 2 \mathrm{H}_{2} \mathrm{O}$. Observed decreases in viscosity were to values that are commensurate with fill-finish in manufacture and/or subcutaneous injection i.e. in the range of $15 \mathrm{cP}$ and lower. However, calcium salts of DPA and QA are of limited aqueous solubility and it may be necessary to identify salt forms that facilitate $\mathrm{mAb}$ formulation studies at concentrations employed typically in current mAb formulations i.e. 50 to $150 \mathrm{mM}$. In terms of potential mechanisms of action, structural perturbation of $\mathrm{mAb} \mathrm{A}$ - in the presence of DPA salts in particular - was confined to localised mobilisation of aromatic side chains, at least as adjudged from intrinsic fluorescence analyses. More general conformational changes involving gross changes 
to the protein secondary structural elements or surface hydrophobicity were not detected using calorimetric or fluorescence reporter dye-based techniques. With this in mind - and since proteinprotein interactions involving reversible self-association may involve exposed hydrophobic aromatic residues (Geoghegan et al., 2016) - it seems reasonable to hypothesise that the attenuation of temperature-induced phase separation of mAb A by DPA salts is promoted by preferential interactions with accessible aromatic side chains. A similar mode of localised conformational destabilisation of mAbs induced by Arg has also been proposed (Thakkar et al., 2012), whereas structural changes to protein tertiary structure are thought to be associated with binding of Arg to aromatic Trp and Tyr side chains (Wen et al., 2015). Accordingly, local structural changes to mAb A observed in the presence of DPA are not an indication of incompatibility with protein formulation. Notably, mAb A formulations containing the Arg salt of QA were associated with the lowest viscosity and opalescence, but displayed enhanced intrinsic fluorescence intensity. This may be related to an increase in the stability of the IgG domains in the presence of Arg.QA, detected as a small enthalpic gain by DSC.

\section{Conclusion}

In conclusion, this work introduces a new class of organic acids - inspired by their association with bacterial spores - as novel excipients in the context of protein formulation. We suggest that future work, at least in the medium term, should aim to elucidate further the mode of action of DPA and QA salts on $\mathrm{mAb}$ stability, characterise further the effects on $\mathrm{mAb}$ stability, and identify salts that are suitable for scaling up during manufacture.

\section{Acknowledgements}

The authors thank the financial support from MedImmune.

\section{References}


Du, W., Klibanov, A.M., 2011. Hydrophobic salts markedly diminish viscosity of concentrated protein solutions. Biotechnol. Bioeng. 108, 632-636.

Fukuda, M., Kameoka, D., Torizawa, T., Saitoh, S., Yasutake, M., Imaeda, Y., Koga, A., Mizutani, A., 2014. Thermodynamic and fluorescence analyses to determine mechanisms of IgG1 stabilization and destabilization by arginine. Pharm. Res. 31, 992-1001. Geoghegan, J.C., Fleming, R., Damschroder, M., Bishop, S.M., Sathish, H.A., Esfandiary, R., 2016. Mitigation of reversible self-association and viscosity in a human IgG1 monoclonal antibody by rational, structure-guided Fv engineering, mAbs. Taylor \& Francis, pp. 1-10.

Higgins, D., Dworkin, J., 2012. Recent progress in Bacillus subtilis sporulation. FEMS Microbiol. Rev. 36, 131-148.

Kameoka, D., Masuzaki, E., Ueda, T., Imoto, T., 2007. Effect of buffer species on the unfolding and the aggregation of humanized IgG. J. Biochem. 142, 383-391.

Kamerzell, T.J., Esfandiary, R., Joshi, S.B., Middaugh, C.R., Volkin, D.B., 2011. Protein-excipient interactions: Mechanisms and biophysical characterization applied to protein formulation development. Adv. Drug Delivery Rev. 63, 1118-1159.

Kheddo, P., Golovanov, A.P., Mellody, K.T., Uddin, S., van der Walle, C.F., Dearman, R.J., 2016.

The effects of arginine glutamate, a promising excipient for protein formulation, on cell viability:

Comparisons with NaCl. Toxicol. In Vitro 33, 88-98.

Kheddo, P., Tracka, M., Armer, J., Dearman, R.J., Uddin, S., van der Walle, C.F., Golovanov, A.P., 2014. The effect of arginine glutamate on the stability of monoclonal antibodies in solution. Int. J. Pharm. 473, 126-133.

Kim, N.A., Hada, S., Thapa, R., Jeong, S.H., 2016. Arginine as a protein stabilizer and destabilizer in liquid formulations. Int. J. Pharm. 513, 26-37.

Lee, H.H., Choi, T.S., Lee, S.J.C., Lee, J.W., Park, J., Ko, Y.H., Kim, W.J., Kim, K., Kim, H.I., 2014. Supramolecular inhibition of amyloid fibrillation by cucurbit [7] uril. Angew. Chem., Int. Ed. 53, $7461-7465$. Middaugh, C.R., Weis, D.D., Volkin, D.B., 2013. Correlating excipient effects on conformational and 
storage stability of an IgG1 monoclonal antibody with local dynamics as measured by

hydrogen/deuterium-exchange mass spectrometry. J. Pharm. Sci. 102, 2136-2151.

McKenney, P.T., Driks, A., Eichenberger, P., 2013. The Bacillus subtilis endospore: assembly and functions of the multilayered coat. Nat. Rev. Microbiol. 11, 33-44.

Paredes-Sabja, D., Setlow, P., Sarker, M.R., 2011. Germination of spores of Bacillales and Clostridiales species: mechanisms and proteins involved. Trends Microbiol. 19, 85-94.

Salinas, B.A., Sathish, H.A., Bishop, S.M., Harn, N., Carpenter, J.F., Randolph, T.W., 2010.

Understanding and modulating opalescence and viscosity in a monoclonal antibody formulation. $\mathrm{J}$. Pharm. Sci. 99, 82-93.

Schneider, C.P., Shukla, D., Trout, B.L., 2011. Arginine and the Hofmeister series: The role of ionion interactions in protein aggregation suppression. J. Phys. Chem. B 115, 7447-7458.

Setlow, P., 2014. Germination of spores of Bacillus species: what we know and do not know. J. Bacteriol. 196, 1297-1305.

Shire, S.J., Shahrokh, Z., Liu, J., 2004. Challenges in the development of high protein concentration formulations. J. Pharm. Sci. 93, 1390-1402.

Tan, I.S., Ramamurthi, K.S., 2014. Spore formation in Bacillus subtilis. Environ. Microbiol. Rep. 6, 212-225.

Thakkar, S.V., Kim, J.H., Samra, H.S., Sathish, H.A., Bishop, S.M., Joshi, S.B., Volkin, D.B., Middaugh, C.R., 2012. Local dynamics and their alteration by excipients modulate the global conformational stability of an $\operatorname{lgG} 1$ monoclonal antibody. J. Pharm. Sci. 101, 4444-4457.

Tsumoto, K., Umetsu, M., Kumagai, I., Ejima, D., Philo, J.S., Arakawa, T., 2004. Role of arginine in protein refolding, solubilization, and purification. Biotechnol. Prog. 20, 1301-1308.

Wen, L., Chen, Y., Liao, J., Zheng, X., Yin, Z., 2015. Preferential interactions between protein and arginine: effects of arginine on tertiary conformational and colloidal stability of protein solution. Int. J. Pharm. 478, 753-761.

Zhang, J., Frey, V., Corcoran, M., Zhang-van Enk, J., Subramony, J.A., 2016. Influence of Arginine Salts on the Thermal Stability and Aggregation Kinetics of Monoclonal Antibody: Dominant Role of Anions. Mol. Pharmaceutics 13, 3362-3369. 


\section{Figure Captions}

385

Figure 1 - DSC thermograms of mAb A solutions (1 mg/mL) under different buffer conditions: (a)

$25 \mathrm{mM}$ His $120 \mathrm{mM} \mathrm{NaCl} \mathrm{pH} 6$ (solid grey line); 10mM DPA 57.5mM His 120mM NaCl pH 6

(dashed line); $10 \mathrm{mM} \mathrm{Ca}(\mathrm{OH})_{2}$ 10mM DPA 25mM His $120 \mathrm{mM} \mathrm{NaCl} \mathrm{pH} 6$ (dotted line); $20 \mathrm{mM} \mathrm{Arg}$

10mM DPA $25 \mathrm{mM}$ His $120 \mathrm{mM} \mathrm{NaCl} \mathrm{pH} 6$ (solid black line). (b) $25 \mathrm{mM}$ His $120 \mathrm{mM} \mathrm{NaCl} \mathrm{pH} 6$

(solid grey line); 10mM QA 57.5mM His $120 \mathrm{mM} \mathrm{NaCl} \mathrm{pH} 6$ (dashed line); 10mM Ca(OH) $)_{2} 10 \mathrm{mM}$

QA 25mM His 120mM NaCl pH 6 (dotted line); 20mM Arg 10mM QA 25mM His 120mM NaCl pH 6 (solid black line).

393

Figure 2 - Fluorescence Intensity of mAb A at $330 \mathrm{~nm}(1 \mathrm{mg} / \mathrm{mL}$ in $25 \mathrm{mM}$ His $120 \mathrm{mM} \mathrm{NaCl} \mathrm{pH} \mathrm{6)}$

with different concentrations of DPA (filled grey circles), $\mathrm{Ca}^{2+}$-DPA (filled black squares), Arg-DPA

(2:1 molar ratio) (open black triangles), QA (stars), $\mathrm{Ca}^{2+}-\mathrm{QA}$ (filled black diamonds), and Arg-QA

(2:1 molar ratio) (open grey circles) $(\mathrm{N}=6)$.

398

399

Figure 3 - Temperature of hydrophobicity of mAb A in the presence of DPA, $\mathrm{Ca}^{2+}$-DPA, Arg-DPA

400

(2:1 molar ratio), QA, $\mathrm{Ca}^{2+}-\mathrm{QA}$, and Arg-QA (2:1 molar ratio) determined by $\mathrm{DSF}(\mathrm{N}=3)$.

401

402

Figure 4 - Absorbance at $450 \mathrm{~nm}$ of mAb A $(50 \mathrm{mg} / \mathrm{mL}$ in $25 \mathrm{mM}$ His $120 \mathrm{mM} \mathrm{NaCl} \mathrm{pH} \mathrm{6;} \mathrm{filled}$ circles) in the presence of $10 \mathrm{mM} \mathrm{CaCl}_{2} \cdot 2 \mathrm{H}_{2} \mathrm{O}$ (stars), $10 \mathrm{mM} \mathrm{Ca}^{2+}$-DPA (diamonds), $10 \mathrm{mM} \mathrm{Ca}^{2+}-\mathrm{QA}^{2}$ (down triangles), 20mM Arg. $\mathrm{HCl}$ (open circles), 20mM Arg 10mM DPA (open triangles), and 20mM Arg 10mM QA (open squares) at different temperatures.

406

Figure 5 - Viscosity measurements using m-VROC (Rheosense, Inc.) of $150 \mathrm{mg} / \mathrm{ml} \mathrm{mAb} \mathrm{A} \mathrm{in} 25 \mathrm{mM}$

His $120 \mathrm{mM} \mathrm{NaCl} \mathrm{pH} 6$ (labelled ' $\mathrm{mAb} \mathrm{A}$ ') in the presence of the following excipients: $10 \mathrm{mM}$

$\mathrm{CaCl}_{2} \cdot 2 \mathrm{H}_{2} \mathrm{O}\left(\mathrm{CaCl}_{2}\right), 10 \mathrm{mM} \mathrm{Ca}{ }^{2+}-\mathrm{QA}(\mathrm{Ca}-\mathrm{QA}), 10 \mathrm{mM} \mathrm{Ca}{ }^{2+}$-DPA (Ca-DPA), 20mM Arg. $\mathrm{HCl}$ 


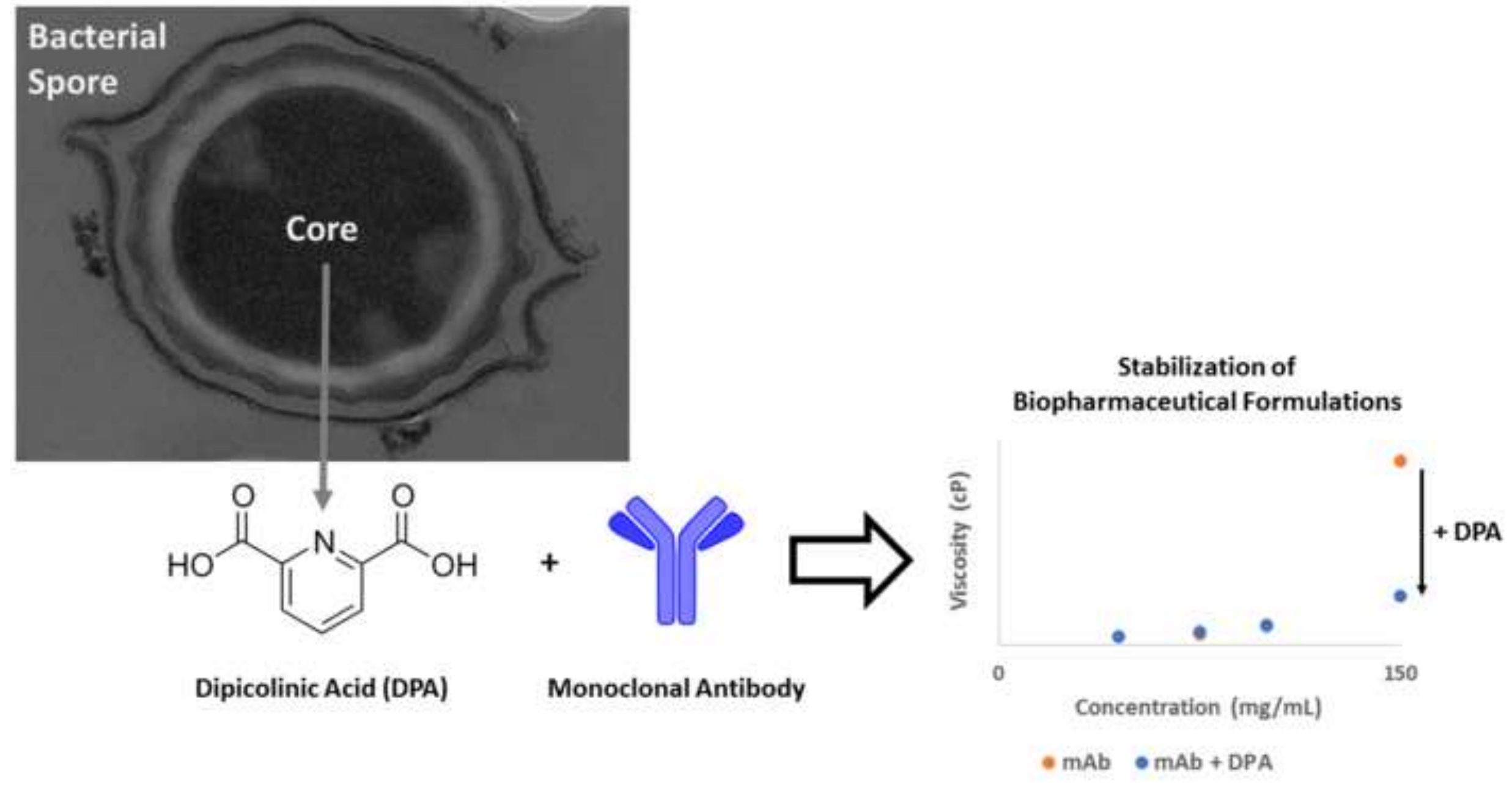


a)

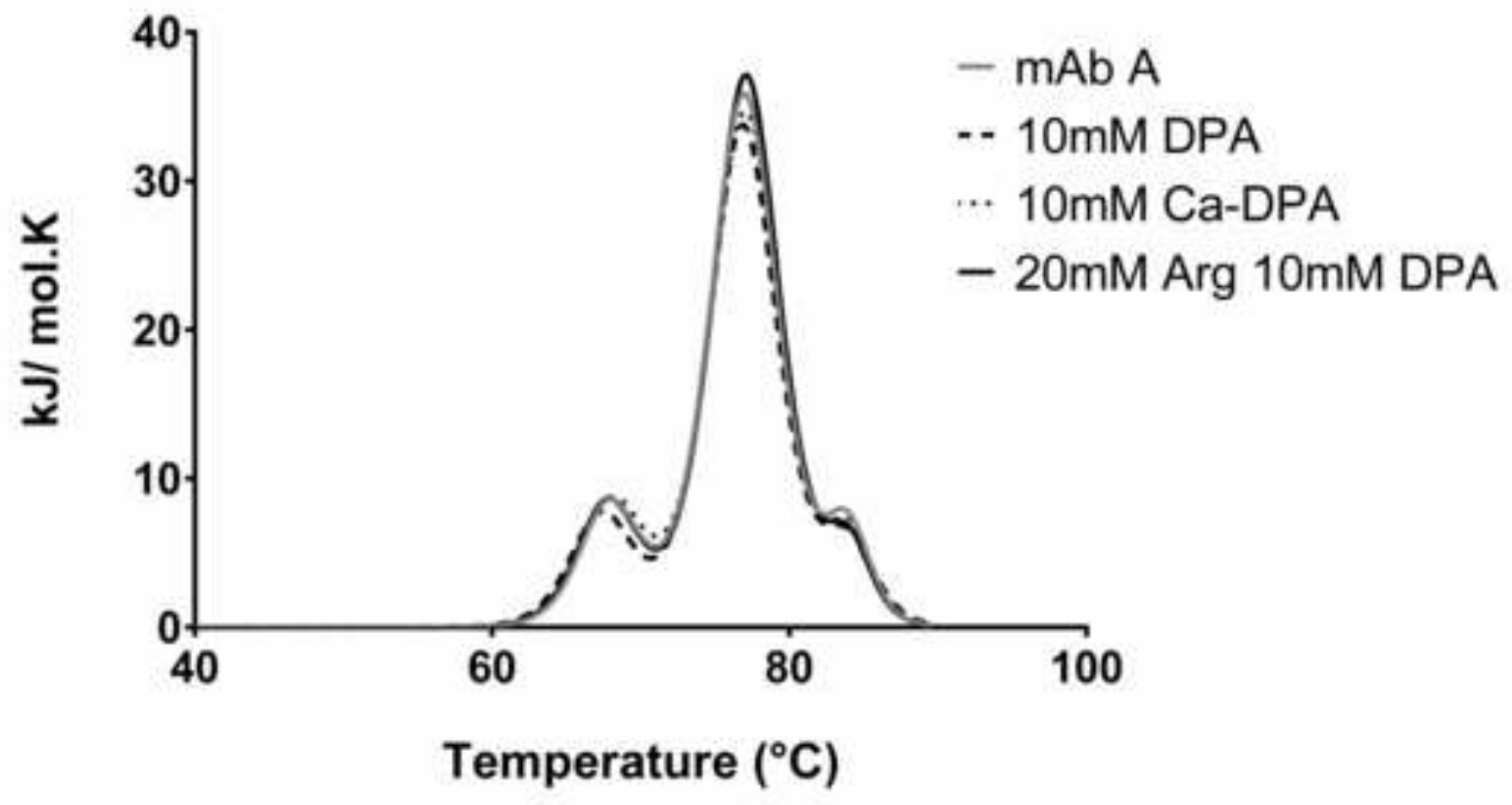

b)

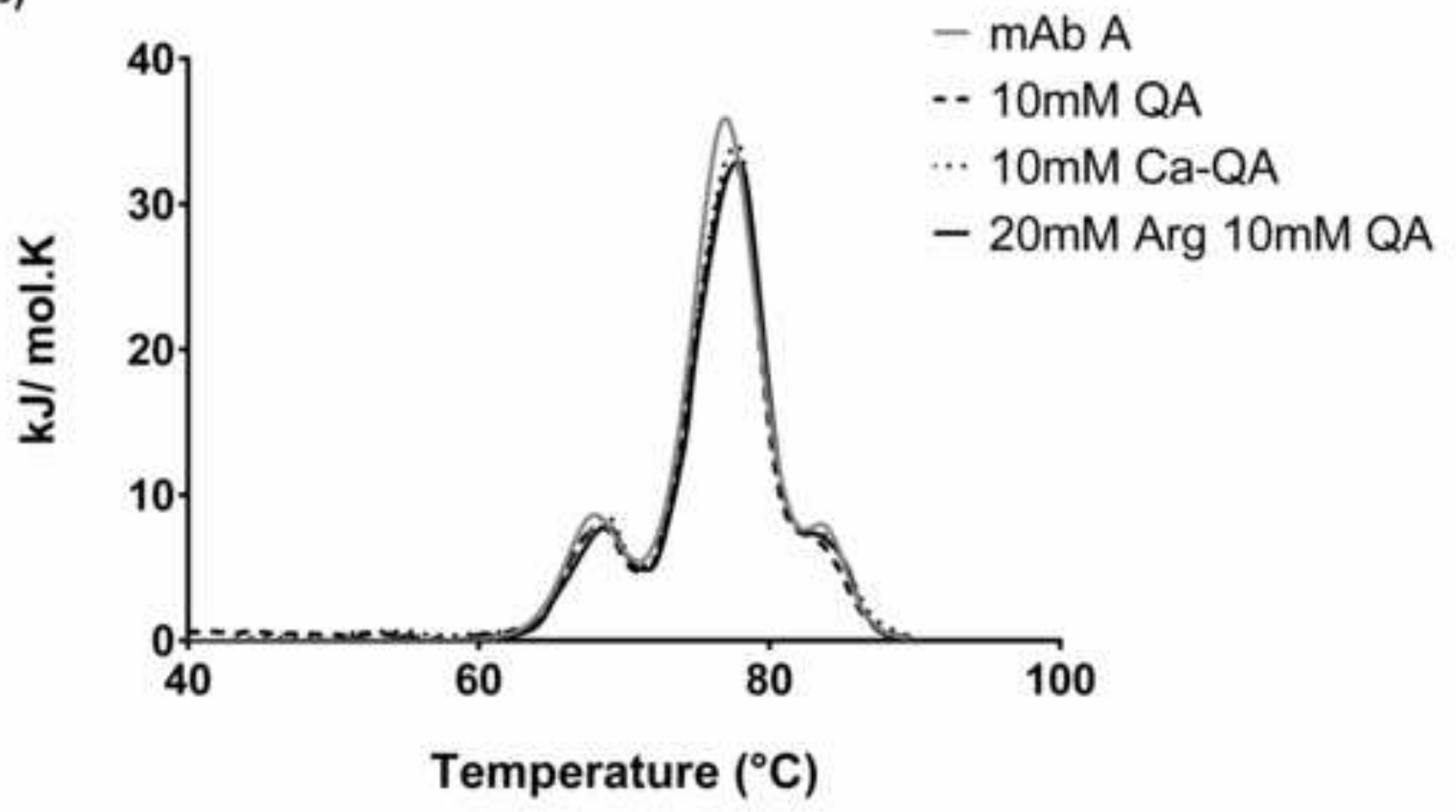




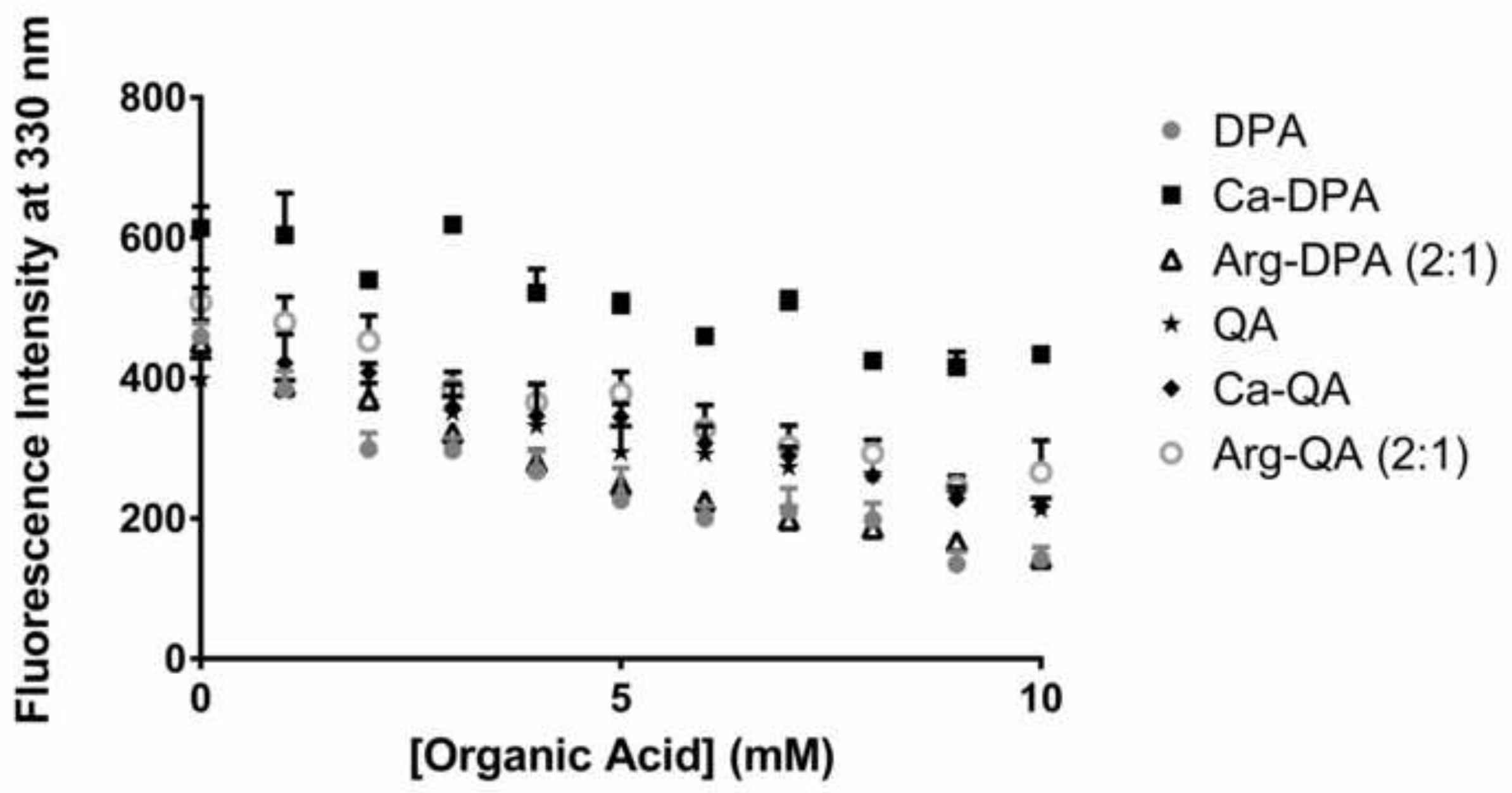




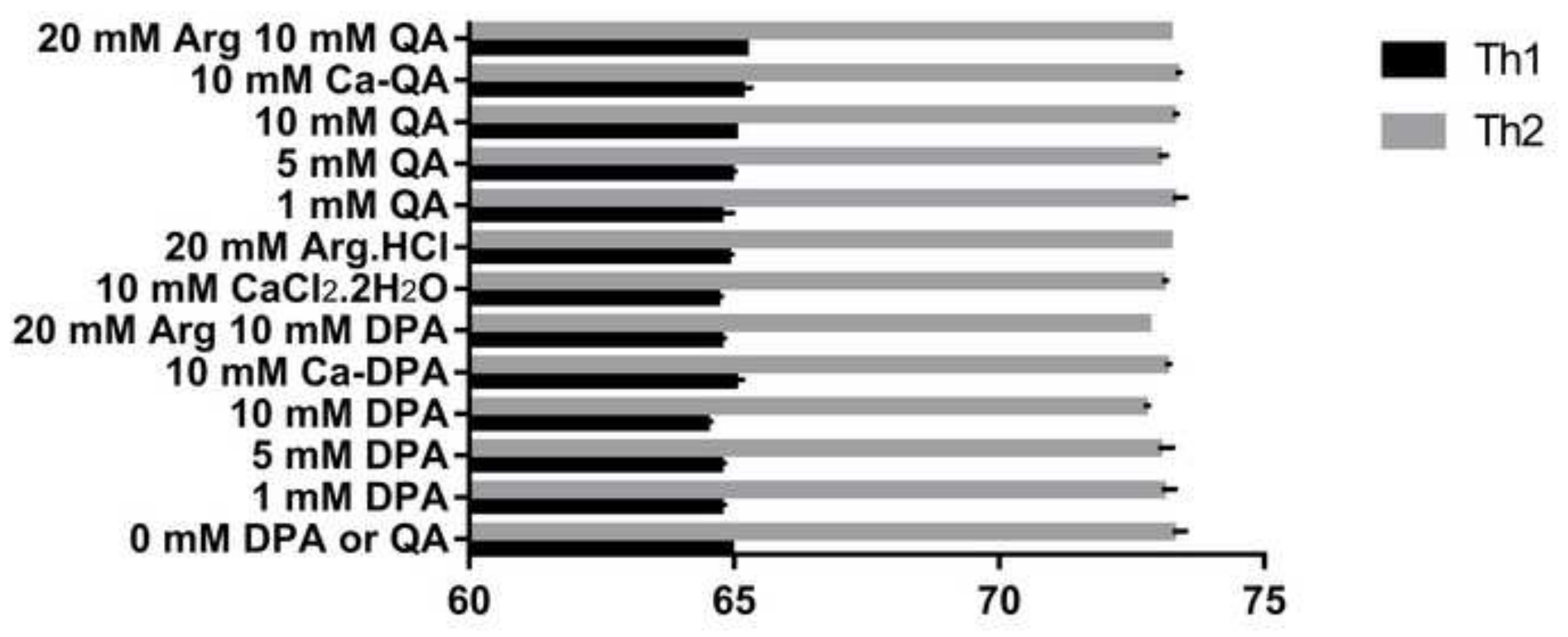

\section{Temperature $\left({ }^{\circ} \mathrm{C}\right)$}




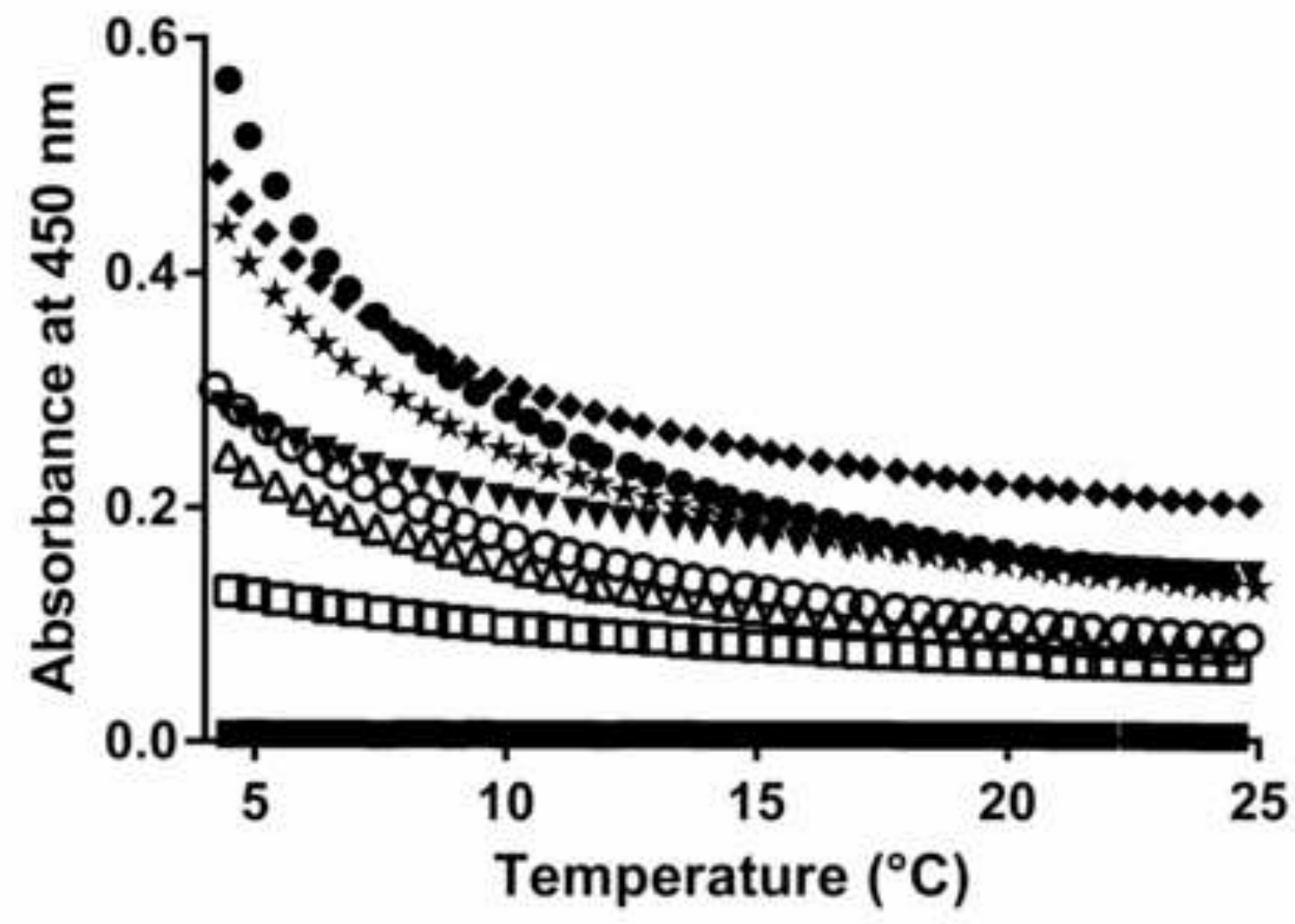

- mAb A

- mab A Ca-DPA

v mAb A Ca-QA

* mAb A CaCl $2 \cdot 2 \mathrm{H}_{2} \mathrm{O}$

- mAb A Arg. $\mathrm{HCl}$

- mAb A Arg-QA (2:1)

$\triangle \quad m A b$ A Arg-DPA (2:1)

- Buffer 


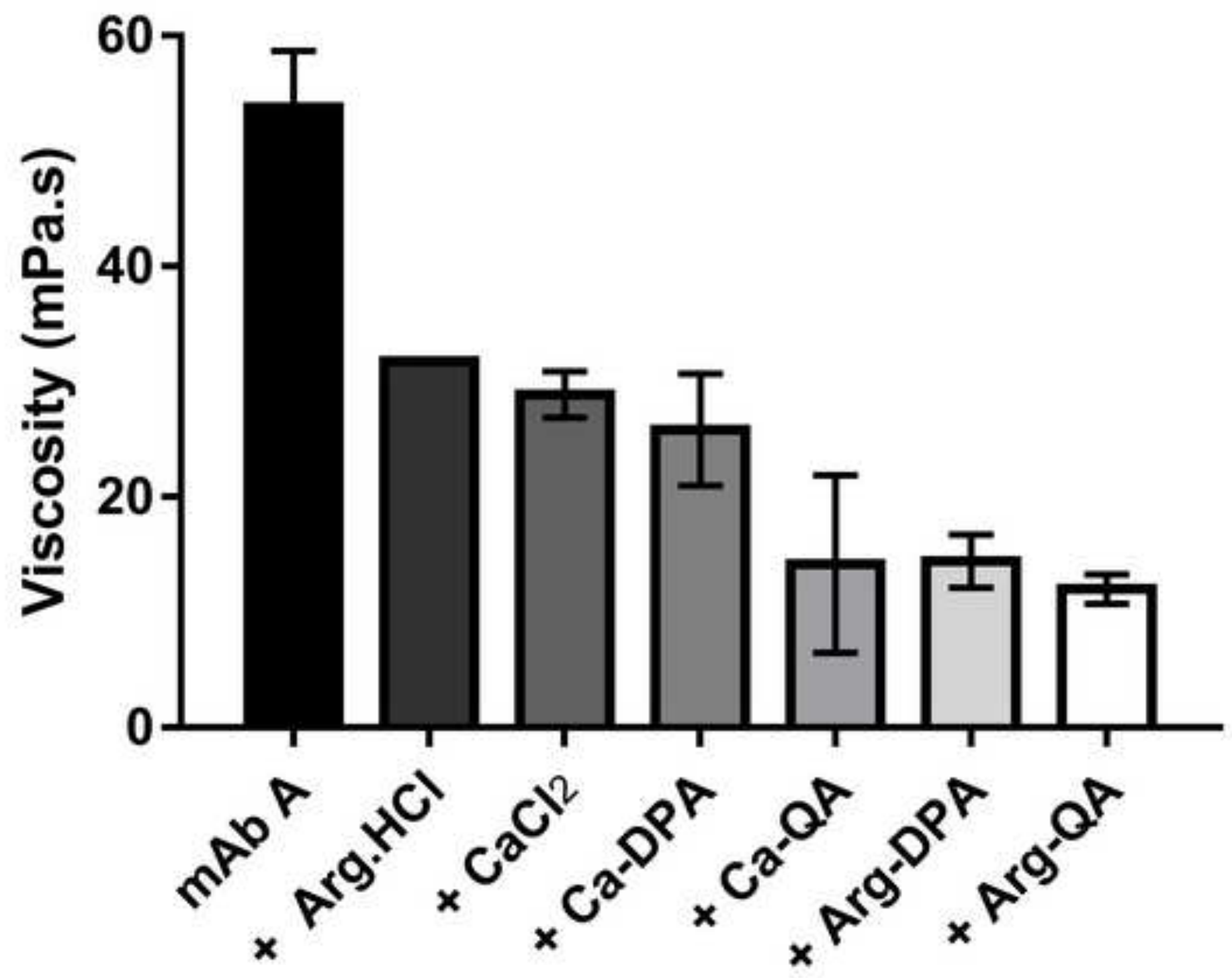

